\title{
Marine vessels alter the behaviour of bottlenose dolphins Tursiops truncatus in the Istanbul Strait, Turkey
}

\author{
Aylin Akkaya Bas ${ }^{1,2,3, *}$, Fredrik Christiansen ${ }^{4}$, Bayram Öztürk ${ }^{1,2}$, \\ Ayaka Amaha Öztürk ${ }^{1,2}$, Mehmet Akif Erdoğan ${ }^{3,5}$, Laura Jane Watson ${ }^{3}$ \\ ${ }^{1}$ Istanbul University, Faculty of Fisheries, 34452 Beyazit, Istanbul, Turkey \\ ${ }^{2}$ Turkish Marine Research Foundation, PO Box 10, Beykoz, Istanbul 81650, Turkey \\ ${ }^{3}$ Marine Mammals Research Association, Kuskavagi Mah. 543 Sok. No.6/D, 07070 Antalya, Turkey \\ ${ }^{4}$ Cetacean Research Unit, School of Veterinary and Life Sciences, Murdoch University, Murdoch, Western Australia 6150, \\ Australia \\ ${ }^{5}$ Geographical Information System Division, Department of Architecture and Urban Planning, Cukurova University, \\ 01350 Adana, Turkey
}

\begin{abstract}
The non-lethal impacts of marine vessels on cetaceans are now a globally recognised threat. This study is the first to investigate the effect of marine traffic on the behaviour of bottlenose dolphins Tursiops truncatus in the Istanbul Strait, Turkey. The Istanbul Strait (also known as the Bosphorus) is one of the busiest international waterways in the world and is exposed to dense marine traffic. The effect of marine traffic, location and season on the behavioural transitions was investigated through general log-linear analysis. Further, the changes on the behavioural budget and bout duration were assessed using Markov chains. Results showed that marine vessels were the main driving force for the behavioural transitions. These changes in transitions between behaviours led to significant changes in behavioural budget and bout durations (average time in each behavioural state). Surface-feeding, resting and socialising behaviour significantly decreased in the control budget, while diving showed an increase in the presence of vessels. Moreover, dolphins spent less time surface-feeding, resting, socialising and diving once disrupted. Furthermore, the current level of vessel-dolphin interaction $(51 \%)$ in the Istanbul Strait was sufficiently high to alter the dolphins' cumulative behavioural budget significantly. Finally, speed and distance of vessels played a considerable role in the directional responses of dolphins. These results raise concerns on the potential biological consequences of the observed behavioural changes, considering that the population is already classified 'at risk' and is still lacking species-specific conservation plans. The results of the study must be considered immediately to create protected zones in order to mitigate the vessel-dolphin interactions.
\end{abstract}

KEY WORDS: Bottlenose dolphins - Marine traffic - Disturbance - Behavioural impacts · Behavioural budgets $\cdot$ Bout lengths $\cdot$ Cumulative behaviour $\cdot$ Markov chain $\cdot$ Conservation

\section{INTRODUCTION}

Intense and accelerated development of the world's coastline is increasing the interaction between coastal marine mammal species and anthropogenic-

*Corresponding author: akkayaaylinn@gmail.com related activities (Notarbartolo di Sciara 2002). Due to the steady increase in marine traffic both at the local and global scale, various studies have investigated the effects of marine vessel interactions on marine mammals over the past decades and under-

() The authors 2017. Open Access under Creative Commons by Attribution Licence. Use, distribution and reproduction are unrestricted. Authors and original publication must be credited. 
lined the importance of management actions to minimise potential negative effects (Richardson et al. 1995a, Lemon et al. 2006, Ameer 2008, Kight \& Swaddle 2011). The effects of underwater noise on marine fauna have attracted a great deal of interest in recent years, and this scientific discipline has unveiled several previously unknown relationships that have all contributed towards much more effective management and conservation practices around the globe (Buckstaff 2004, Foote et al. 2004, Aguilar et el. 2006, Holt et al. 2012, Williams et al. 2015). Specifically, interactions between marine traffic and cetaceans have been the focus of considerable research effort over recent years, with particular attention being paid to bottlenose dolphins Tursiops truncatus (Nowacek et al. 2001, Lusseau 2003, 2005, 2006, Lusseau et al. 2006, Campana et al. 2015).

Cetacean species have previously demonstrated behavioural changes and/or habituation in response to marine vessel pressure. Dusky dolphins Lagenorhynchus obscurus (Barr \& Slooten 1999, Dans et al. 2008), common dolphins Delphinus delphis (Stockin et al. 2008, Meissner et al. 2015), Indo-Pacific humpback dolphins Sousa chinensis (Van Parijs \& Corkeron 2001), sperm whales Physeter macrocephalus (Gordon et al. 1992), minke whales Balaenoptera acutorostrata (Christiansen et al. 2013), Hector's dolphins Cephalorhynchus hectori (Bejder et al. 1999) and bottlenose dolphins (Nowacek et al. 2001, Hastie et al. 2003, Lusseau 2004, Lusseau et al. 2006, Christiansen et al. 2010, Pirotta et al. 2015, Perez-Jorge et al. 2017), have demonstrated both short- and longterm behavioural changes in response to marine vessels within a wide range of ecological settings. Such changes can take on various forms, with the most frequent being variations in vocalization, an increase in dive intervals, both vertical and horizontal avoidance behaviour, an increase in swimming speed, and a decrease in foraging and resting behaviour (Lusseau 2004, Stockin et al. 2008, Christiansen et al. 2010, 2013, Meissner et al. 2015). By contrast, cases exist whereby habituation may be particularly advantageous to the population as a whole. A population of killer whales Orcinus orca was able to habituate to deliberate noise pollution; they avoided harassment devices set along lines during their initial encounters, but quickly established a way in which to overcome such noise disturbance (Tixier et al. 2015).

The Istanbul Strait (also known as the Bosphorus; $41^{\circ} 13^{\prime}$ to $41^{\circ} 00^{\prime} \mathrm{N}, 29^{\circ} 08^{\prime}$ to $28^{\circ} 59^{\prime} \mathrm{E}$ ) is situated between the Black Sea and the Marmara Sea, and is one of the narrowest straits in the world, with a minimum distance of $698 \mathrm{~m}$ between the European and Asian coasts. It is not only a vitally important marine ecosystem (Öztürk \& Öztürk 1996), but represents an area of great strategic, economic and cultural value (Öztürk \& Öztürk 1996, Köse et al. 2003, Atar \& Ates 2009). For centuries, the Istanbul Strait has been the most important route for oil transportation between the Black Sea and the Mediterranean Sea, as it is the only waterway between these basins (Özsoy et al. 2016). The strait is also home to heavy domestic and international marine traffic. The annual number of marine vessels travelling through the Istanbul Strait was approximately 4500 in 1936 . This figure has since increased dramatically to 45529 marine vessels passing through the strait in 2014 (Kara 2016). Regarding the daily traffic, the number of cargo ships is estimated on average to be around 130 and the local traffic alone amounts to more than 2500 vessels per day (Directorate General of Coastal Safety 2014). Adding to its economic significance, the Istanbul Strait is an important fish migration path and contains critical habitats for cetacean species (Öztürk \& Öztürk 1996, Atar \& Ates 2009, Bas et al. 2015). Bottlenose dolphins, common dolphins and harbour porpoises Phocoena phocoena are regularly observed within the strait (Öztürk \& Öztürk 1996).

Monitoring of behavioural changes can be used to determine the effect of boat presence and, if the level of exposure is known, can then be extrapolated to determine the overall effect on the population. Various authors (e.g. Saulitis et al. 2000, Lusseau 2003, 2004, Stockin et al. 2008, Christiansen et al. 2010, Meissner et al. 2015) have utilized behavioural budgets via the creation of Markov chains as a tool to assess disturbances in various cetacean populations, with particular focus on marine vessel pressure. However, it is important to keep in mind that studying the effect of marine traffic can involve some limitations, given that cetaceans spend most of their time underwater and some of their behavioural reactions might be elusive to the observer (New et al. 2014, Pirotta et al. 2015).

The aim of the current study was to determine the effects of marine vessels on the behaviour of bottlenose dolphins. More specifically, we investigated the effects of boat presence on the dolphins' behavioural budget and bout duration. To help inform management, we also investigated the effect of vessel speed, distance and vessel density on swimming direction of the bottlenose dolphins, in order to understand what specific factors are causing disturbance. 


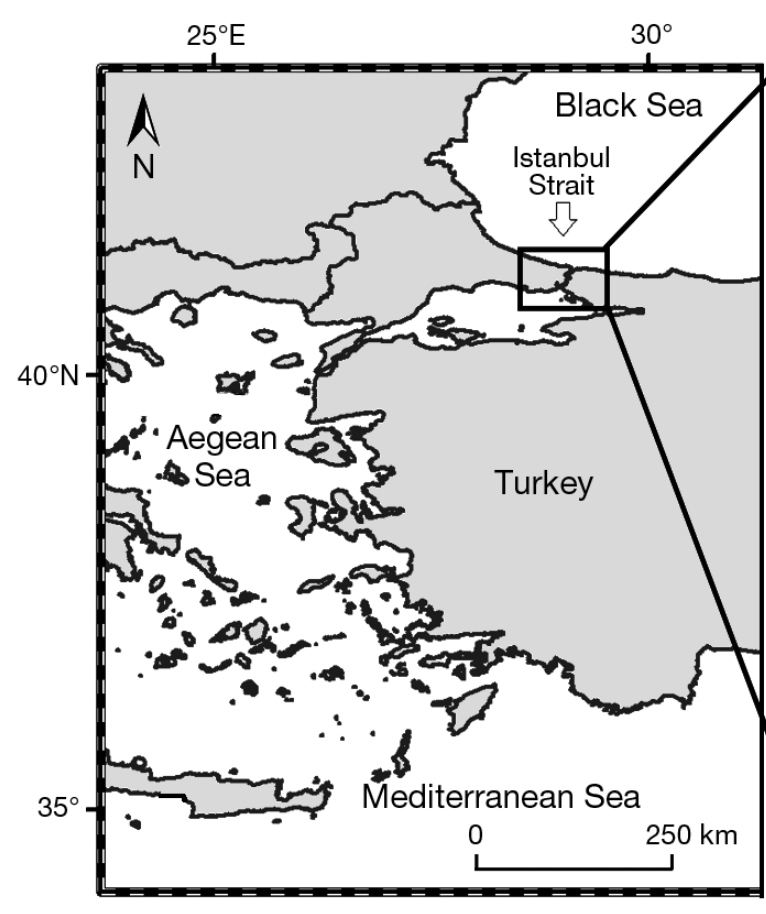

MATERIALS AND METHODS

\section{Study area}

The study area covered the entire Istanbul Strait, including the adjacent waters of the Sea of Marmara and the Black Sea. For the purpose of this study, the Istanbul Strait was divided into 4 sections based on vessel density and traffic patterns (Fig. 1). A total of 7 land observation stations were selected in the 4 different sections: south section (Ahirkapi Lighthouse); middle section (Ulus Park, Rumeli Castle); middle-north section (Hidiv Kasri); and north section (Rumeli Kavagi, Garipce, Anadolu Lighthouse) (Fig. 1). All stations were on the coast and at least $30 \mathrm{~m}$ above sea level for accurate theodolite readings (Table 1).

Table 1. Coordinates and altitude of each station in the Istanbul Strait, Turkey

\begin{tabular}{|c|c|c|c|}
\hline \multirow[t]{2}{*}{ Stations } & \multicolumn{2}{|c|}{ Coordinates } & \multirow{2}{*}{$\begin{array}{l}\text { Altitude } \\
\text { (m) }\end{array}$} \\
\hline & $\mathrm{N}$ & E & \\
\hline Ahirkapi Lighthouse & $41^{\circ} 0^{\prime} 22^{\prime \prime}$ & $28^{\circ} 59^{\prime} 8^{\prime \prime}$ & 38 \\
\hline Ulus Park & $41^{\circ} 3^{\prime} 42^{\prime \prime}$ & $29^{\circ} 2^{\prime} 11^{\prime \prime}$ & 30 \\
\hline Rumeli Castle & $41^{\circ} 5^{\prime} 3^{\prime \prime}$ & $29^{\circ} 3^{\prime} 21^{\prime \prime}$ & 44 \\
\hline Hidiv Kasri & $41^{\circ} 6^{\prime} 18^{\prime \prime}$ & $29^{\circ} 4^{\prime} 25^{\prime \prime}$ & 90 \\
\hline Rumeli Kavaği & $41^{\circ} 10^{\prime} 41^{\prime \prime}$ & $29^{\circ} 4^{\prime} 22^{\prime \prime}$ & 45 \\
\hline Garipçe & $41^{\circ} 12^{\prime} 44^{\prime \prime}$ & $29^{\circ} 6^{\prime} 36^{\prime \prime}$ & 45 \\
\hline Anadolu Lighthouse & $41^{\circ} 13^{\prime} 3^{\prime \prime}$ & $29^{\circ} 9^{\prime} 8^{\prime \prime}$ & 55 \\
\hline
\end{tabular}

Data were collected in systematic weekly landbased surveys, between September 2011 and October 2013. Each station was visited on at least 2 different days each month. During the surveys, data were collected between 06:00 and 21:00 h. The field team included a theodolite operator, a computer operator, a behaviour and sightings data collector, and 2 spotters responsible for scanning the sea surface in search of cetaceans. The geographic position of vessels and bottlenose dolphins was recorded using a FOIF theodolite paired with Pythagoras v. 1.2 (Texas A\&M University). The distance from the centre of the group to the nearest vessels was measured with the Pythagoras software. When vessels and cetaceans were present at the same time, coordinates were recorded alternately for the vessels and the focal group. Further, regardless of dolphin presence, the number of marine vessels and their type was counted every $10 \mathrm{~min}$ throughout the land surveys, to estimate the marine vessel density of each station.

Marine vessels were divided into 9 different categories: HSB (high-speed boat); FB (fishing boat, $<10 \mathrm{~m}$ in length); FV (fishing vessel, >10 $\mathrm{m}$ in length, usually equipped with a sonar system); RB (research boat); FE (ferry, <15 knot [kn]); SB (sea bus, >15 kn); SCS (small commercial cargo, <200 $\mathrm{m}$ in length); BCS (big commercial cargo, >200 $\mathrm{m}$ in length); and IDLE (all stationary or very slow-moving [<2 kn] vessels). 
Directional changes of dolphins in relation to the nearest vessel were categorised as either (1) response, when dolphins swam away or towards a vessel; or (2) no response, when dolphins kept a constant direction despite vessel presence. Marine vessels were placed within 1 of 3 speed categories: slow vessels (idle speed up to $3 \mathrm{kn}$ ); medium vessels (3 to $9 \mathrm{kn}$ ); and fast vessels (9 kn and upwards).

All sightings and effort data, as well as environmental conditions (visibility and cloud cover percentage, and Beaufort scale) were recorded, in addition to the theodolite data collection. Surveys were conducted only up to Beaufort scale 3. Seasons were classified as spring (March to May), summer (June to August), autumn (September to November) and winter (December to February).

\section{Behavioural sampling}

To determine the behaviour demonstrated by the focal group, a focal 'group' scan sampling method was adopted (Christiansen et al. 2010, Meissner et al. 2015). Behaviours of individuals in a group were scanned from one side of the group to the other, and the predominant behaviour (the behavioural state that $>50 \%$ of the group was engaged in) of the group was recorded every 3 min after their initial sighting. Dolphin groups were defined as individuals engaging in similar behaviours, with close-group cohesion (<50 m). Recorded behavioural states were identified as travelling, diving, surface-feeding, milling, resting, or socialising (Table 2). Previous studies combined diving and surface-feeding behaviour under either a diving or foraging state (Neumann 2001,
Lusseau, 2003, Constantine et al. 2004, Stockin et al. 2008, Meissner et al. 2015). However, due to the uncertainty of determining if dolphins were actually foraging during the diving state, we separated these 2 behavioural states into diving and surface-feeding (Table 1). The sample sizes for resting and socialising were too small to include them both individually in the analysis. Therefore, these 2 behavioural states were merged into one (socialising-resting) and analysed together.

When the distance between marine vessels and the centre of the focal group was $\leq 400 \mathrm{~m}$, marine vessel presence was recorded as 'present' and referred to as the 'impact zone'. However, when the distance between a vessel and the focal group was $>400 \mathrm{~m}$, vessel presence was recorded as 'absent' and referred to as the 'control zone'. This limit of $400 \mathrm{~m}$ was selected based on previous studies in other geographical areas (Constantine \& Baker 1997, Bejder \& Samuels 2003, Lusseau 2003, Bain et al. 2006, Bejder et al. 2006a) and on a study in the same area, which showed that the probability of harbour porpoises responding to vessels was less than $10 \%$ when vessels were beyond $400 \mathrm{~m}$ (Bas et al. in press). The results of the current study also justified the significant drop in the directional changes beyond $400 \mathrm{~m}$.

\section{Behavioural transitions}

First-order time-discrete Markov chain analyses are a widely applied method to quantify the 1-way dependence of a behavioural state on the immediately preceding behavioural state, which allows for the potential effect of any factor on the dependence of

Table 2. Definition of each behavioural state (Lusseau 2003, 2004, Constantine et al. 2004, Christiansen et al. 2010)

\begin{tabular}{ll} 
Behavioural state & \multicolumn{1}{c}{ Definition } \\
\hline Travelling (TR) & $\begin{array}{l}\text { Dolphins engage in persistent and directional movement, and make noticeable headway with } \\
\text { constant speed }(>2 \mathrm{kn}) \text {. Dive intervals are relatively short }(<60 \mathrm{~s}) \text { and constant. } \\
\text { Coordinated steep dives, usually tails are out at the surface before the dive. Dive intervals are long. } \\
\text { No obvious, steady movements are recorded. Group spacing varies. }\end{array}$ \\
$\begin{array}{l}\text { Surface-feeding } \\
\text { (SU-FE) }\end{array}$ & $\begin{array}{l}\text { Dolphins chase fish with rapid circular dives, uncoordinated re-entry leaps, and rapid directional } \\
\text { changes and circle swimming. Prey often observed at the sea surface or in the dolphin's mouth, along } \\
\text { with ripples. No body contact. }\end{array}$ \\
Milling (MI) & $\begin{array}{l}\text { Non-directional movement and frequent changes in bearing. Animals do not make headway in any } \\
\text { specific direction. Although the group movement varies, group cohesion stays similar. Individuals } \\
\text { can face in different directions. Dive intervals are short }\end{array}$ \\
Dolphins observed within a tight group $(<5$ m), and although movement is synchronous and steady, \\
swimming speed is low $(<2$ kn) with short dive intervals $(<30$ s). Group activity level is low with no \\
splashing at the surface.
\end{tabular}


the behavioural states to be assessed (Lusseau 2003, 2004, Stockin et al. 2008). Therefore, the preceding and following behavioural states were recorded for control and impact situations in order to create the transition probability matrix for the Markov chains. 'Preceding' behavioural states $(P)$ essentially represent the first group behavioural state recorded (at $t$ min time), and 'following' behavioural states $(F)$ represent the follow-up behavioural state (at $t+3 \mathrm{~min}$ time). Behavioural contingency tables ( $P$ vs. $F$ ) were developed both for control and impact chains in order to investigate the temporal dependence between behavioural states (Lusseau 2003, Christiansen et al. 2010, 2013, Meissner et al. 2015). Control situation represented no vessels present (within $400 \mathrm{~m}$ of the focal group) between the preceding and following behavioural states. If marine vessels were present within $400 \mathrm{~m}$ of the focal group, the transition between preceding and following behavioural states was added to the impact situation table. However, due to constant marine vessel presence within the Istanbul Strait, it was impossible to have a definite control chain, thus only 9 min of continuous boat absence was considered a control chain, and sampling periods $<9$ min were discarded due to the uncertainty of the situation. Moreover, it is important to note that it is very likely that vessels were still present outside the reaction zone even during control situations.

\section{Data analysis}

General log-linear analysis for model selection

A general log-linear analysis was used to determine the best-fitting model in regard to behavioural transitions between preceding and following behavioural states, and to test the effect of the following 3 factors: marine vessels; season; and location (detailed in Lusseau 2003). The model's null hypothesis stated that the following behavioural state was independent of marine vessel presence, season and location, given the preceding behavioural state. All possible models were tested until the saturated model was reached and the best-fitting model was chosen based on the lowest Akaike's information criterion (AIC).

Behavioural transition probabilities

To delineate the temporal dependence of behaviours, transition probability matrices were created by determining the transition probabilities from a preceding to a following behavioural state both during impact (behaviours in the presence of vessels) and control (behaviours in the absence of vessels for at least 9 min) situations (Lusseau 2003):

$$
p_{i j}=\frac{a_{i j}}{\sum_{j=1}^{5} a_{i j}}, \sum p_{i j}=1
$$

where $p_{i j}$ is the transition probability from the preceding behavioural state, $i$, to the following behavioural state, $j$ ( $i$ and $j$ range from 1 to 5 , as there were 5 behavioural states used in this study; see Table 2), $a_{i j}$ is the number of transitions observed from behaviour $i$ to $j$ and $\sum a_{i j}$ is the total number of observations where $i$ is the preceding state (Lusseau 2003). To test the effect of vessel interaction on the transition probability, the impact and control contingency tables were compared using a chi-squared test, where the observed count was represented by the impact chain (with a sample size equal to control chain) and the expected count was represented by the control chain. Further, each impact transition was compared to its corresponding control transition, using a 2-sample test for equality of proportions with continuity correction (Christiansen et al. 2010).

\section{Behavioural budgets}

To assess changes in behavioural budgets for impact and control situations, Eigen-analysis of both the control and impact matrices was performed (Lusseau 2003, 2004). Differences between the control and impact budgets were tested using a chisquared test (Fleiss 1981, Lusseau 2003). Each behavioural state within the control behavioural budget was also compared to the corresponding behavioural state within the impact behavioural budget, using a 2 -sample test for equality of proportions with continuity correction. The $95 \%$ confidence intervals were calculated for the estimated proportion of time spent within each behavioural state following Lusseau (2003).

\section{Cumulative behavioural budgets}

The diurnal effect of marine vessels on dolphin behavioural budgets was investigated by calculating the cumulative behavioural budget and comparing it to the control (undisturbed) budget of the dolphins. The cumulative behavioural budget takes 
into account the proportion of time that dolphins spend in the presence of vessels (impact situation) over a specified period of time (i.e. a day). By artificially varying this proportion from 0 to $100 \%$, it is possible to determine at what level of exposure the cumulative behavioural budget becomes significantly affected, assuming that observed effect size does not vary with daytime exposure rate (Lusseau 2004). The cumulative behavioural budget (Lusseau 2004, Christiansen et al. 2010) was calculated as:

$$
=(a \times \text { impact budget })+(b \times \text { control budget })
$$

where $a$ represents the proportion of time that dolphins spend with vessels and $b$ is the remaining proportion of time $(1-a)$ without the vessel presence. The difference between the cumulative behavioural budget and the control budget was tested with a chisquared test and 2-sample test for equality of proportions with continuity correction for each behavioural state (Fleiss 1981, Christiansen et al. 2010).

\section{Bout lengths}

Average bout lengths (the duration of time spent in a given state) of each behavioural state $\overline{t_{i i}}$ was estimated for both the control and impact chain, as described by Lusseau $(2003,2004)$ :

$$
\begin{aligned}
\overline{t_{i i}} & =\frac{1}{1-p_{i i}} \\
\text { with } \mathrm{SE} & =\sqrt{\frac{p_{i i} \times\left(1-p_{i i}\right)}{n_{i}}}
\end{aligned}
$$

where $n_{i}$ is the number of samples with $i$ as preceding behavioural state. Bout lengths were compared between the control and impact situation using a Student's $t$-test.

All statistical analyses were carried out with R.3.1.1 (R Core Team 2014)

\section{Directional changes}

To investigate which vessel-related variables affect the behaviour of the dolphins, directional changes of the dolphins as a function of distance to the nearest vessel, the speed of the vessels (slow, medium and fast) and the number of vessels within $400 \mathrm{~m}$ of the dolphins were investigated. The directional changes were divided into response versus no response, so that a generalized linear model (GLM) with a binomial distribution (response as a binary variable) and a logit link function could be fitted to the data. To account for overdispersion in the models, the standard errors were corrected using a quasi-GLM model where the variance is given by $\phi \times \mu$, where $\mu$ is the mean and $\phi$ the dispersion parameter. Temporal autocorrelation and uneven sample sizes between follows was accounted for by including only the first data point from each follow in the analyses. Collinearity (high correlation) between the explanatory variables was investigated by estimating the variance inflation factor, with an upper threshold value of 3 indicating collinearity. The best-fitting model was selected using AIC.

\section{RESULTS}

\section{Bottlenose dolphin sightings and marine vessel presence}

Surveys were carried out over the course of $308 \mathrm{~d}$ $(1631 \mathrm{~h})$, of which bottlenose dolphins were encountered on $164 \mathrm{~d}$ (204 h) (Table 3). The survey effort for each season was similarly distributed, whereas it was unequal between sections, with the north section having the highest and middle-north the lowest survey effort (Table 3). Overall bottlenose dolphin sighting rate was highest in the south and north sections, with over 86 and $56 \%$, respectively. The middle section had the lowest number of dolphin sightings for each season with an average of $28 \%$. Spring was the season with the highest dolphin sighting rate $(75 \%)$, while autumn had the lowest (34\%).

Bottlenose dolphins were exposed to marine vessels during $51 \%$ of the time. However, when considering only periods of continuous 9 min vessel absence, it was found that dolphins spent ca. $65 \%$ of

Table 3. Days of survey effort per season and section within

\begin{tabular}{|c|c|c|c|c|c|}
\hline \multirow[t]{2}{*}{ Season } & \multicolumn{4}{|c|}{$\longrightarrow$ Section } & \multirow[t]{2}{*}{ Effort } \\
\hline & North & $\begin{array}{l}\text { Middle- } \\
\text { north }\end{array}$ & Middle & South & \\
\hline Spring & $36(34)$ & $6(4)$ & $17(7)$ & $13(13)$ & 72 \\
\hline Summer & $39(31)$ & $7(3)$ & $25(10)$ & $9(6)$ & 80 \\
\hline Autumn & $38(5)$ & $5(1)$ & $22(4)$ & $16(14)$ & 81 \\
\hline Winter & $33(12)$ & $5(1)$ & $17(2)$ & $20(17)$ & 75 \\
\hline Effort & $146(82)$ & $23(9)$ & $81(23)$ & $58(50)$ & 308 \\
\hline
\end{tabular}
the Istanbul Strait. Numbers in brackets represent days of bottlenose dolphin sightings. Effort represents total survey effort 


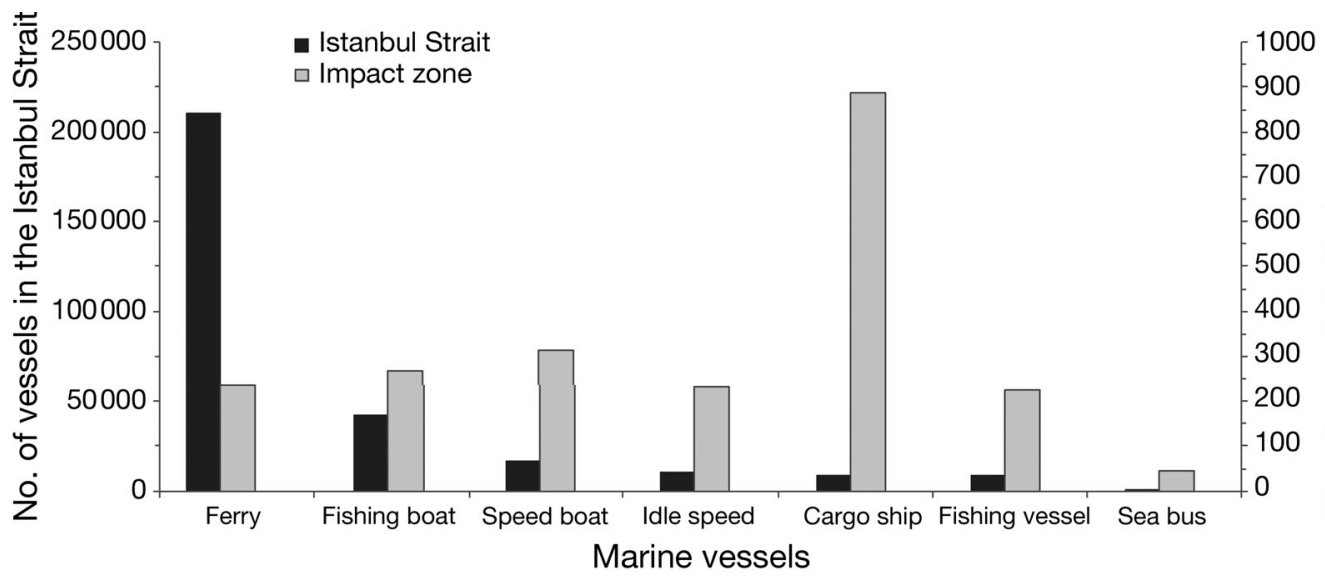

Fig. 2. Number of each type of vessel that was present both within the $400 \mathrm{~m}$ and the overall count between 2011 and 2013 in the Istanbul Strait

their time in the presence of marine vessels, as most control situations were limited to less than $3 \mathrm{~min}$.

Small cargo ships were the dominant vessel type during interactions, followed by fishing boats. Together, these 2 vessel types represented $40 \%$ of total interactions. In contrast, sea buses were the lowest recorded vessel type during dolphin interactions, representing only $2 \%$ of encounters (Fig. 2). Irrespective of dolphin presence, an assessment of marine traffic and the prevalence of vessel types revealed that a total of 301247 vessels used the Istanbul Strait during the study period, with ferries representing $70 \%$ of vessels. Despite the dominance of ferries within the strait, they were sighted in the vicinity $(<400 \mathrm{~m})$ of dolphins only $11 \%$ of the time throughout the $2 \mathrm{yr}$ study (Fig. 2). Moreover, we found that $13 \%$ of marine traffic within the strait was actually stationary (IDLE category), represented mostly by fishing boats. With respect to the selected sections in the Istanbul Strait, $60 \%$ of the total vessel traffic was present within the middle section of the strait. On average, around 500 vessels were recorded daily throughout this middle section, whereas only 40 vessels were typically observed within the northern sections on a daily basis.

\section{General log-linear analysis for model selection}

A total of 3913 behavioural samples were collected throughout the study, which corresponded to 617 behavioural transitions under control, and 1497 under impact situations. Overall, dolphins spent most of their time travelling $(44 \%, \mathrm{n}=$
1709) and diving (34\%, $\mathrm{n}=1311)$. Surface-feeding ( $\mathrm{n}=566)$ and milling $(\mathrm{n}=158)$ were observed 14 and $4 \%$ of the time, respectively, whereas socialising $(\mathrm{n}=$ $78)$ and resting $(n=60)$ together represented only $4 \%$ of observations.

The 5-way log-linear analysis showed that the marine vessel model had the lowest AIC value and the highest AIC weight compared to the other models, and was thus found to be the best-fitting model by far (Table 4).

\section{Behavioural transition probabilities}

The temporal dependence between behavioural states of bottlenose dolphins was significantly affected by vessel presence (goodness-of-fit test, $\chi^{2}=$ 171.57, df $=16, \mathrm{p}<0.0001)$. Of the 25 behavioural

Table 4. Model selection on the behavioural transitions. $\times$ indicates an interaction between factors; + indicates the sum of the factors; $G^{2}=$ goodness of fit; $\mathrm{df}=\mathrm{de}$ grees of freedom; AIC $=$ Akaike's information criterion; $\Delta \mathrm{AIC}=$ difference between the best-fitting model and the other models; $\mathrm{MV}=$ marine vessel. Bold: the lowest AIC value

\begin{tabular}{|lccccc|}
\hline Model & $G^{2}$ & df & AIC & $\Delta$ AIC & AIC weight \\
\hline NULL & 485.867 & 620 & -754.13 & 58.775 & $<0.0001$ \\
MV & $\mathbf{3 8 7 . 0 9 2}$ & $\mathbf{6 0 0}$ & $-\mathbf{8 1 2 . 9 1}$ & $\mathbf{0}$ & $\mathbf{0 . 9 9}$ \\
LOCATION & 376.444 & 560 & -743.56 & 69.352 & $<0.0001$ \\
SEASON & 411.255 & 560 & -708.75 & 104.163 & $<0.0001$ \\
MV + LOCATION & 281.2 & 540 & -798.8 & 14.108 & 0.0008 \\
MV + SEASON & 317.694 & 549 & -780.31 & 32.602 & $<0.0001$ \\
LOCATION + SEASON & 296.818 & 500 & -703.18 & 109.726 & $<0.0001$ \\
MV + SEASON + LOCATION & 205.467 & 480 & -754.53 & 58.375 & $<0.0001$ \\
MV $\times$ SEASON & 233.629 & 480 & -726.37 & 86.537 & $<0.0001$ \\
MV $\times$ LOCATION & 238.897 & 480 & -721.1 & 91.805 & $<0.0001$ \\
LOCATION $\times$ SEASON & 216.067 & 320 & -423.93 & 388.975 & $<0.0001$ \\
LOCATION + (MV $\times$ SEASON) & 123.08 & 420 & -716.92 & 95.988 & $<0.0001$ \\
SEASON + $(M V \times$ LOCATION) & 168.221 & 420 & -671.78 & 141.129 & $<0.0001$ \\
MV + (SEASON $\times$ LOCATION) & 121.203 & 300 & -478.8 & 334.111 & $<0.0001$ \\
\hline
\end{tabular}



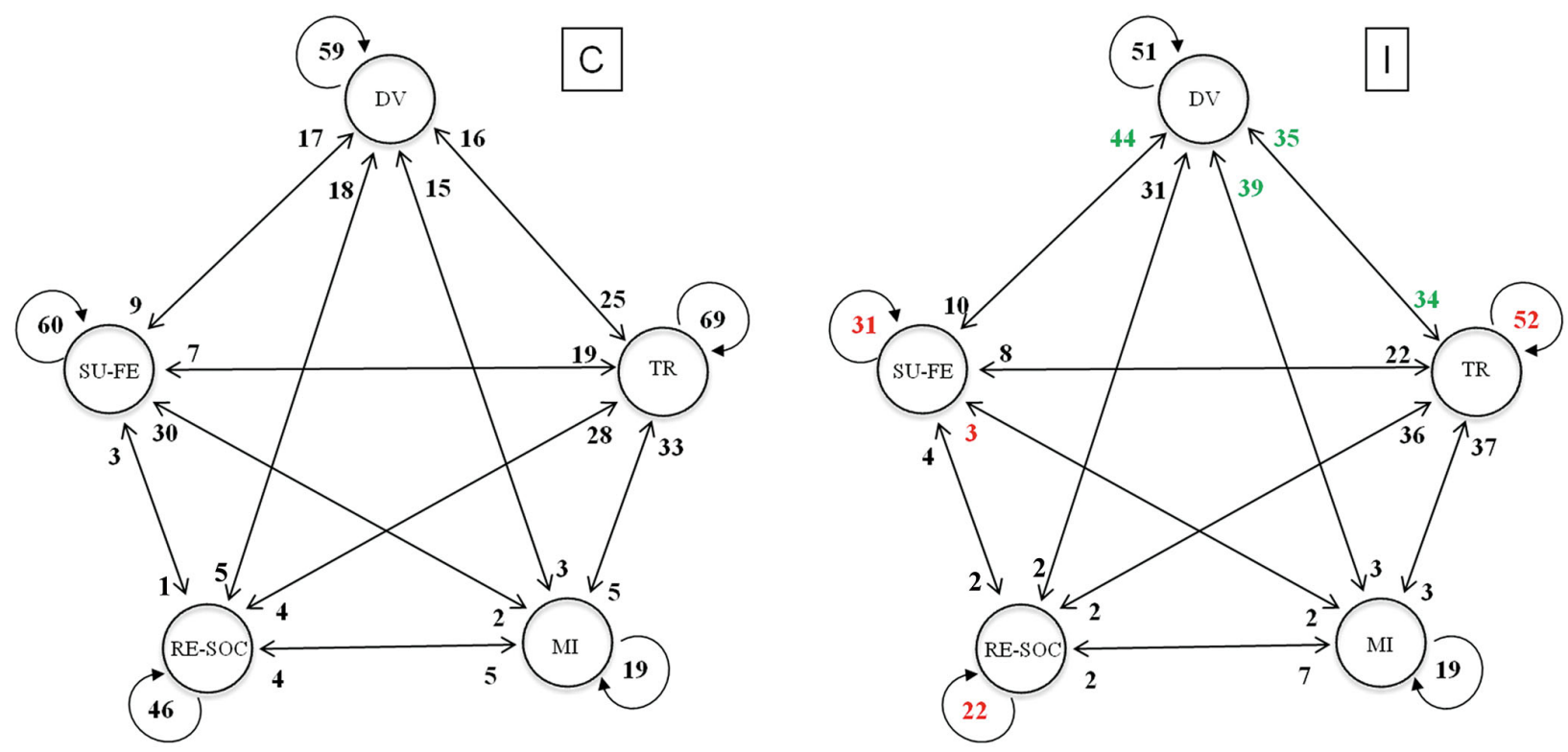

Fig. 3. Markov chains representing probabilities for various behavioural transitions are shown for control (C) and impact (I) chains. The 5 behavioural states are diving (DV), travelling (TR), surface-feeding (SU-FE), milling (MI) and resting-socialising (RE-SOC). Numbers are percentages, and significant changes at the $\mathrm{p}<0.05$ level are shown in colours. Red colours represent a significant decrease and green colours represent a significant increase in the impact chain

transitions, 8 were significantly altered under the presence of vessels (Figs. $3 \& 4$ ). Surface-feeding to surface-feeding $\left(\chi^{2}=21.22, \mathrm{df}=1, \mathrm{p}<0.0001\right)$ and resting-socialising to resting-socialising $\left(\chi^{2}=4.36\right.$, $\mathrm{df}=1, \mathrm{p}=0.04$ ) both significantly decreased by 30 and $24 \%$, respectively, while travelling to travelling decreased by $17 \%\left(\chi^{2}=20.95, \mathrm{df}=1, \mathrm{p}<0.0001\right)$ in the presence of vessels (Figs. $3 \& 4$ ). Further, milling to surface-feeding $\left(\chi^{2}=9.98, \mathrm{df}=1, \mathrm{p}=0.001\right)$ was significantly reduced by $26 \%$ during impact situations. In contrast, the probability of dolphins switching behavioural state to diving increased significantly for 3 of the 5 behavioural states: milling to diving $\left(\chi^{2}=3.96, \mathrm{df}=1, \mathrm{p}=0.047\right)$; surface-feeding to diving $\left(\chi^{2}=17.96, \mathrm{df}=1, \mathrm{p}<0.0001\right)$; and travelling to diving $\left(\chi^{2}=33.45, \mathrm{df}=1, \mathrm{p}<0.0001\right)$; by a magnitude of 24,27 and $20 \%$, respectively (Figs. $3 \& 4$ ). Finally, the probability of dolphins switching from diving to travelling $\left(\chi^{2}=5.44, \mathrm{df}=1, \mathrm{p}=0.020\right)$ increased by $9.4 \%$ during impact situations (Figs. $3 \& 4$ ).

\section{Behavioural budgets}

There was a significant difference between the control and impact behavioural budgets $\left(\chi^{2}=41.89\right.$,

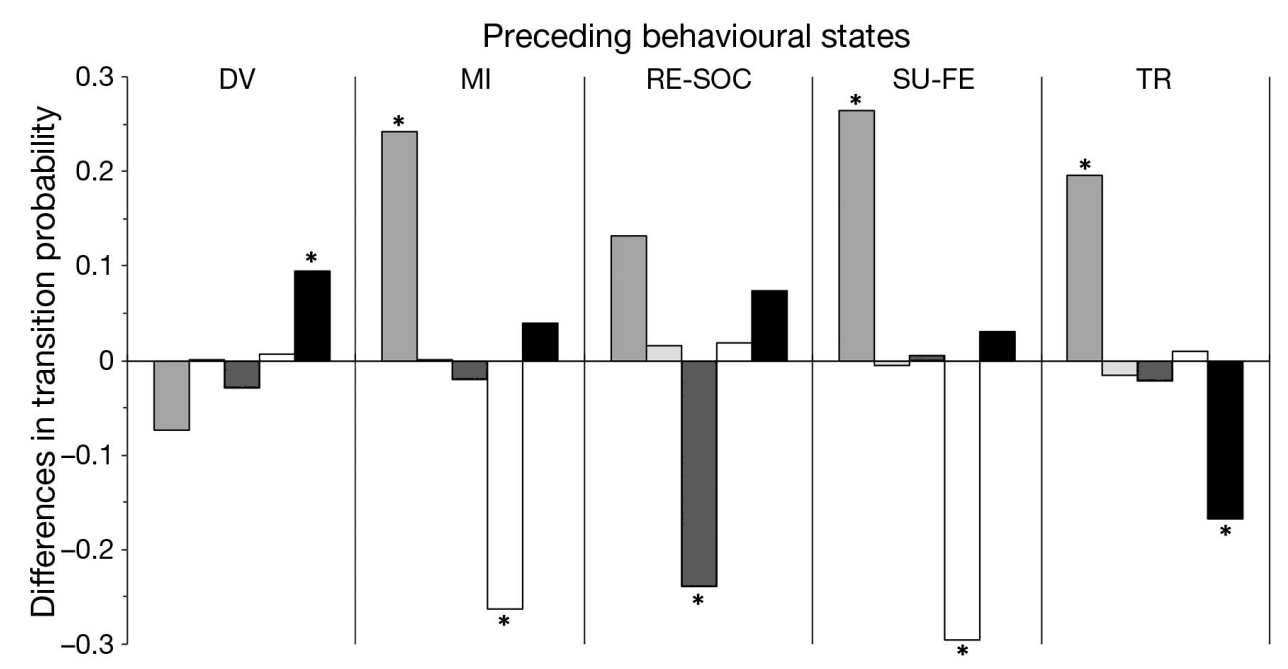

Succeeding behavioural states

$\square \mathrm{DV}$

$\square \mathrm{MI}$

$\square$ RE-SOC

$\square$ SU-FE

- TR

Fig. 4. Differences in behavioural transitions between the control and

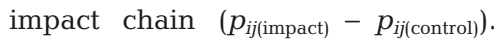
The vertical line separates each preceding behavioural state; shading of bars indicates the succeeding behavioural state. Significant behavioural transitions are indicated $\left({ }^{*} \mathrm{p}<\right.$ 0.05). For abbreviations see Fig. 3 


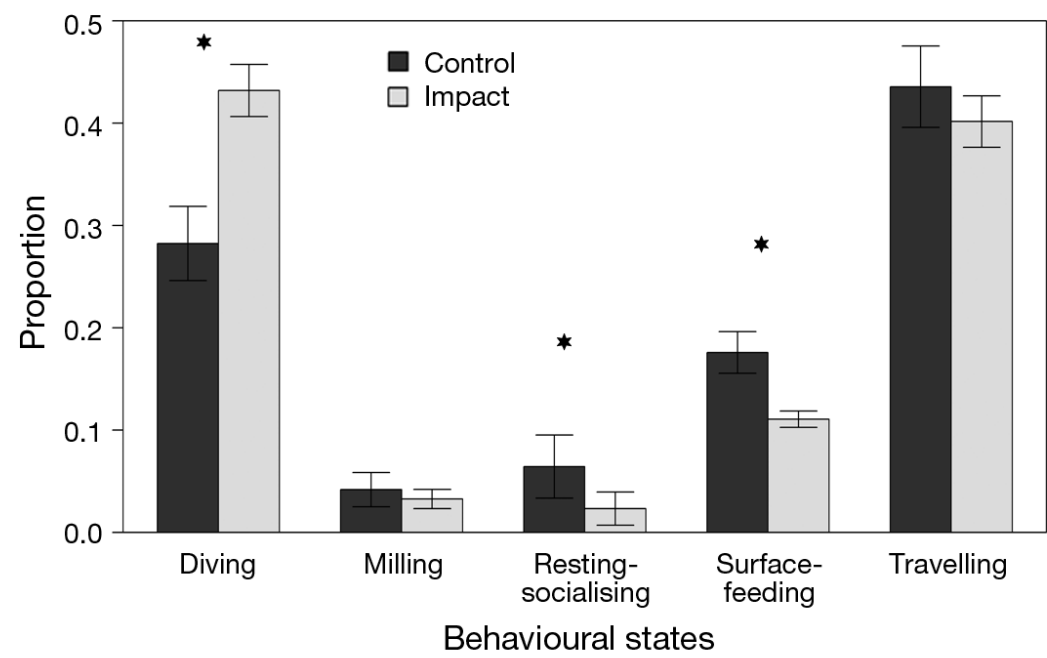

Fig. 5. Stationary probability distribution during the control (black) and impact (grey) budget. Error bars are 95\% confidence intervals. Significant behavioural transitions are indicated $\left({ }^{*} \mathrm{p}<0.05\right)$

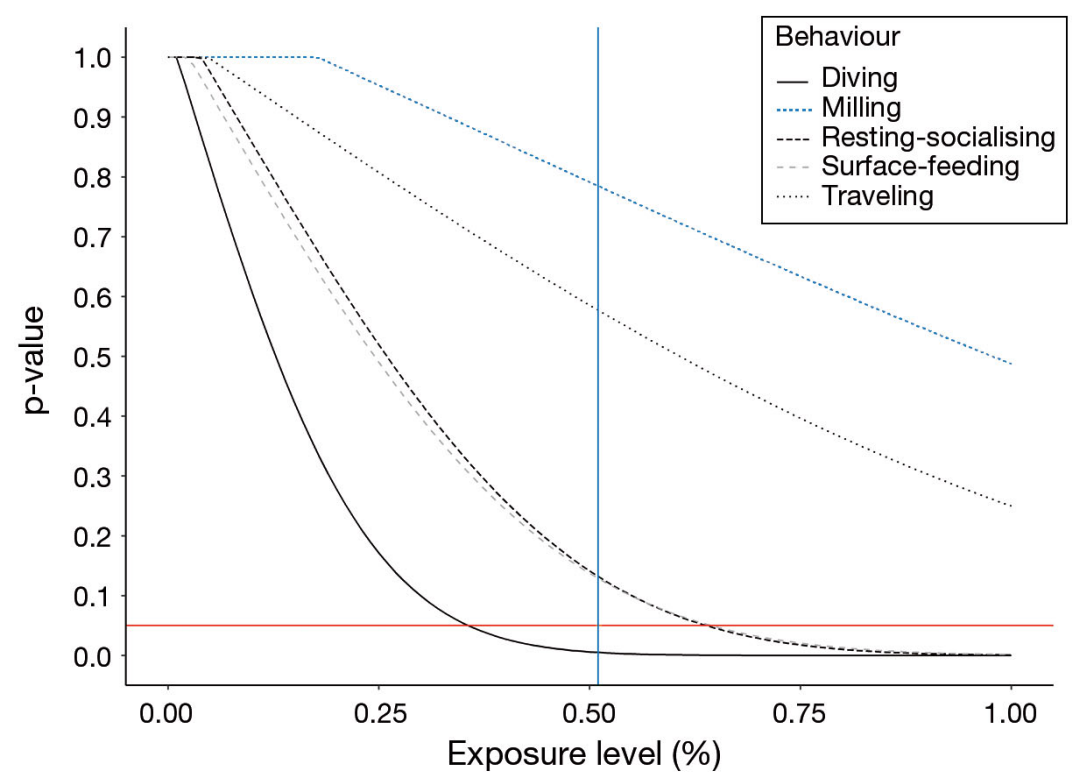

Fig. 6. Changes in the cumulative behavioural budget under different levels of vessel exposure. The $y$-axis represents the p-values for the difference between the cumulative and control behavioural budget for each behaviour. Solid red line represents the statistical level of significance $(p<0.05)$; solid blue line indicates the current exposure level in the Istanbul Strait

ing and socialising-resting represented 17.6 and $6.4 \%$ of the control budget, respectively, but decreased to 11.1 and $2.3 \%$, respectively, during impact situations (surface-feeding: $\chi^{2}=$ 15.89, df $=1, \mathrm{p}<0.0001$; socialisingresting: $\chi^{2}=20.53, \mathrm{df}=1, \mathrm{p}<0.0001$; Fig. 5).

\section{Cumulative behavioural budgets}

At the current level of vesseldolphin interaction (51\%), the dolphins' cumulative behavioural budget was significantly different from their control budget $\left(\chi^{2}=10.64\right.$, df $=$ $4, \mathrm{p}=0.03)$. Diving behaviour was significantly affected when the vessel exposure level reached $36 \%$ of daytime hours (Fig. 6). Further, surface-feeding and resting-socialising were significantly altered when the vessel-dolphin interaction reached $64 \%$ (Fig. 6). In contrast, the cumulative milling and travelling behaviours were not significantly altered, even if the dolphins were to spend all their daylight hours in the presence of vessels (Fig. 6).

\section{Bout lengths}

Of the 5 behavioural states, 4 showed a significant decline in their average bout lengths (min) in the presence of vessels (Fig. 7). The average time that dolphins spent diving was reduced from 7.2 to $6.2 \min (13.9 \%)$ during vessel interactions (Student's $t$-test $=8.71$, df $=$ 757, $\mathrm{p}<$ 0.0001) (Fig. 7). Similarly, the bout length during socialisingresting (Student's $t$-test $=5.73, \mathrm{df}=82$,

df $=4, \mathrm{p}<0.0001$ ) (Fig. 5). While the dominant behaviour in the control budget was travelling, representing $44 \%$ of the overall control budget, it was diving in the impact budget. Regarding each behavioural state, 3 of 5 states showed a significant change. Diving behaviour made up $28 \%$ of the control budget, but increased up to $43 \%$ during the impact budget $\left(\chi^{2}=40.44\right.$, df $\left.=1, p<0.0001\right)$. Surface-feed- $\mathrm{p}<0.0001$ ) and surface-feeding (Student's $t$-test $=$ 17.89, df $=274, \mathrm{p}<0.0001)$ decreased from 5.6 to $3.9 \mathrm{~min}(30.4 \%)$ and from 7.5 to $4.3 \mathrm{~min}(42.7 \%)$, respectively, during impact situations (Fig. 7). Finally, the average bout length during travelling decreased from 9.6 to $6.2 \mathrm{~min}(35.4 \%)$ in the presence of vessels (Student's $t$-test $=31.22$, df $=907$, $\mathrm{p}<0.0001$ ) (Fig. 7). 


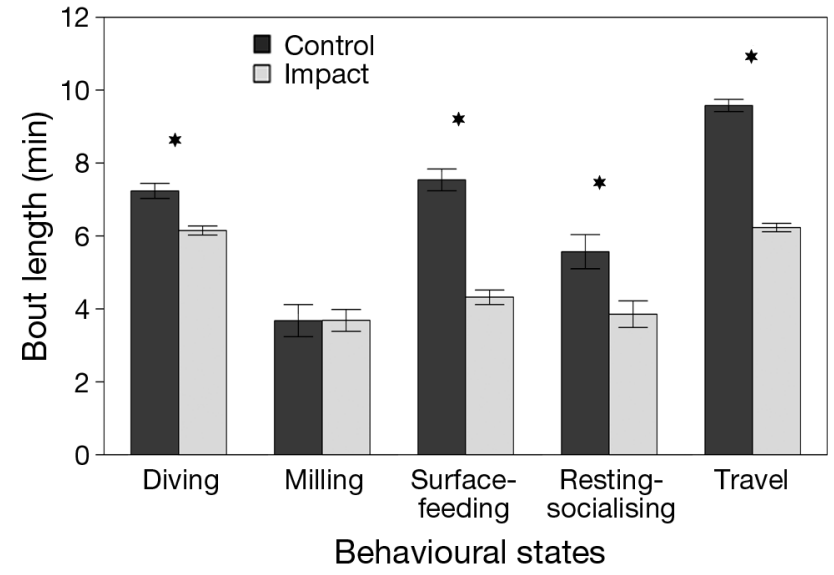

Fig. 7. Bout lengths of each behavioural state during the control (black) and impact (grey) situations. Error bars represent $95 \%$ confidence intervals. Significant behavioural transitions are indicated $\left({ }^{*} \mathrm{p}<0.05\right)$

\section{Directional changes}

Vessel distance $(\mathrm{p}<0.001, \mathrm{n}=721)$ and speed $(\mathrm{p}<$ $0.001, \mathrm{n}=721$ ) both affected the probability of dolphins responding to vessels, whereas vessel numbers did not affect the response of the dolphins. The model explained $30.1 \%$ of the deviance (pseudo- $\mathrm{R}^{2}$ ) in the data. There was no collinearity between the explanatory variables in the best-fitting model. The probability of dolphins avoiding vessels decreased with the distance to the nearest vessel at a rate of $0.011 \pm 0.0018$ (mean \pm SE) on the logit scale (Fig. 8). The probability differed between vessel speed categories, with vessels moving at fast $(1.505 \pm 0.3659$ on logit scale) and medium speed $(0.473 \pm 0.3649$ on logit scale) vessels eliciting a significantly stronger response compared to slow-moving vessels $(-1.600 \pm$ 0.5600 on logit scale) (Fig. 8). The effect of distance did not differ between vessels from different speed categories (there was no interaction term in the model). At close distances $(<10 \mathrm{~m})$, the avoidance probability was around 15, 60 and $80 \%$ for slow-, medium- and fast-moving vessels, respectively. As the distance to the nearest vessel increased, the probability of dolphins showing avoidance responses decreased rapidly to around 5, 35 and $60 \%$ at $100 \mathrm{~m}$ and around 2, 15 and $30 \%$ at $200 \mathrm{~m}$, respectively (Fig. 8). Beyond $400 \mathrm{~m}$, the avoidance probability of dolphins was less than $10 \%$, irrespective of the speed of the vessel (Fig. 8).

\section{DISCUSSION}

Substantial marine vessel traffic exists throughout the Istanbul Strait, with 130 cargo ships and over 2500 local vessels passing through the strait per day (Directorate General of Coastal Safety 2014). The current study shows that marine vessels can significantly affect the behaviour of bottlenose dolphins, with dolphins being more likely to switch from their current behavioural state to diving. These behavioural alterations were visible in the dolphins' behavioural budget, with diving being the predominant behaviour during impact situations, compared to travelling during control situations. Diving behaviour increased by almost $50 \%$, while surface-feeding and already low encounters of resting-socialising behaviour dropped by 40 and $60 \%$, respectively, in the impact budget. Hence it appears that dolphins display vertical avoidance towards vessels, at the cost of

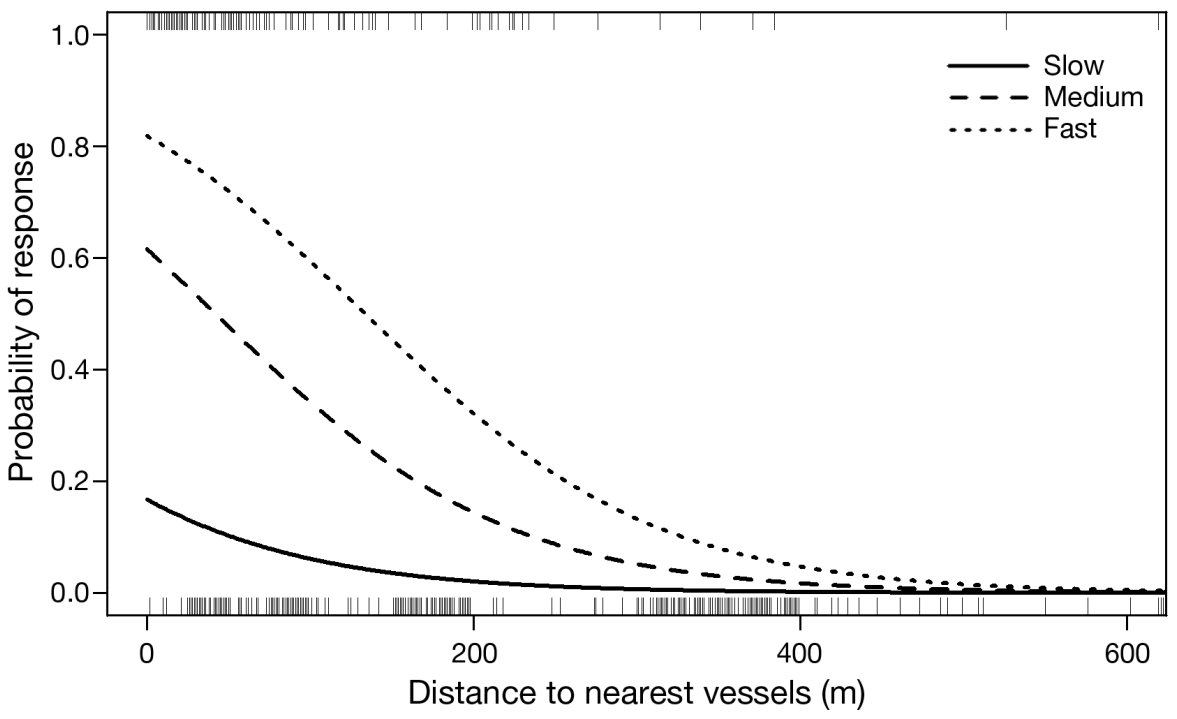

Fig. 8. Probability of dolphins showing an avoidance response towards vessels as a function of the distance to the nearest vessel for slow- (solid line), medium- (dashed line) and fast-moving vehicles (dotted line). The lines represent the fitted values of the best-fitting GLM. The distributions of distance values for dolphins showing an avoidance response and no response are shown by the top and bottom rug plots, respectively. For clarity, only distances up to $600 \mathrm{~m}$ are shown on the $x$-axis (the maximum measured distance was $1468 \mathrm{~m}) . \mathrm{n}=721$ 
reducing the important behaviours of surface-feeding and resting-socialising. Furthermore, the average time that dolphins spent in a given behavioural state was significantly reduced in the presence of vessels, suggesting that the dolphins' behaviour was constantly interrupted by the vessels. Additionally, the current study found out that while speed and distance of the vessel from the dolphin group has a considerable role in the dolphins' swimming direction, vessel density did not cause a significant change in the direction of the animals. The avoidance response was highest at close distance and for faster speed vessels. Marine traffic density throughout the Istanbul Strait is exceptionally high and similar directional changes and behavioural transitions, i.e. increase in diving behaviour and decrease in bout lengths, have been reported in previous studies (Richardson et al. 1995b, Hastie et al. 2003, Aguilar Soto et al. 2006, Bejder et al. 2006a, Neumann \& Orams 2006, Christiansen et al. 2010, Visser et al. 2011, Bas et al. 2015, Meissner et al. 2015). We therefore suggest that regulations which take into account the speed and distance of the vessels, together with an implementation of 'Particularly Sensitive Sea Areas', play fundamental roles in minimising these negative behavioural effects. Repeated behavioural effects can otherwise lead to long-term biological consequences for the survival and reproductive success of individual dolphins, which ultimately (if a significant proportion of the population is affected) can lead to populationlevel effects (Bejder et al. 2006b, Christiansen \& Lusseau 2014, 2015) or area avoidance (Lusseau 2005). Temporal area avoidance might be occurring in the Istanbul Strait with a documented negative relationship between the area used by dolphins and that used by marine vessels (Bas et al. 2015). The middle section of the Istanbul Strait, which is exposed to $>500$ vessels daily, had the lowest number of bottlenose dolphin sightings, while the less busy adjacent waters of the Istanbul Strait (the south and north sections) had the highest dolphin sightings. Further research is needed to verify if this pattern is due to area avoidance or other factors.

In the Istanbul Strait, the current level of vessel exposure $(51 \%)$ is high enough to alter the daily behavioural budget (cumulative budget) of the dolphins, with a significant effect on diving behaviour. If the current vessel exposure increases further, surface-feeding and resting-socialising behaviours are expected to be affected at just over $60 \%$ vessel exposure, which is not far from the current level. That the dolphins' cumulative behavioural budget is affected is alarming, since this indicates that marine vessel pressure in the Istanbul Strait is not occasional, but chronic. Christiansen \& Lusseau (2014) argued that while an animal can compensate for the occasional vessel presence, repeated interactions leave the animals little room to modify their behavioural pattern, and might lead to biologically significant long-term effects.

Vessel presence caused a significant decline in feeding, resting and socialising behaviour. A reduction in feeding can lead to a decrease in energy intake (Christiansen et al. 2013), while a decrease in resting is likely to reduce the energy reserves (Constantine et al. 2004, Lusseau 2004). Over time, alterations to the dolphins' bioenergetic budget can lead to a decrease in body condition, which in turn can have negative effects on survival and reproductive success (New et al. 2014, Christiansen \& Lusseau 2015). Socialising plays an important role for the dolphins' reproductive success and disruption to this behaviour could lead to a lower pregnancy rate, thus fewer offspring, which could have long-term negative biological consequences for the population (Lusseau 2004, 2006, Lusseau et al. 2006, 2011).

The current study revealed that socialising and resting constituted only $6 \%$ of the behavioural budget of the dolphins during control situations, and only $2 \%$ during impact situations. Lusseau (2004) underlined that these rare behavioural states are the most sensitive to disturbance and often the first to translate into long-term changes due to marine traffic in Doubtful and Milford Sounds, New Zealand. Therefore the low proportions of resting and socialising might be related to the high marine vessel density in the area, or they may naturally be low within the Strait but higher somewhere else in the dolphins' home range. Further studies are needed to delineate the potential resting and socialising habitats.

Owing to the extremely high density of marine traffic in the Istanbul Strait, it can be considered as one of the planet's busiest and most important, but also most hazardous and narrow, channels (Birkun 2002, Köse et al. 2003, Mavrakis \& Kontinakis 2008). The amount of marine traffic has increased steadily since the early 1990s (Deniz \& Durmuşoğlu 2008) and this trend is likely to continue in coming decades. Even though bottlenose dolphins in the area are already classified as 'at risk' (Birkun 2012), there are no species-specific conservation and management plans in Turkey, despite the numerous threats they are facing, including overfishing, habitat destruction and bycatch (Öztürk \& Öztürk 1996, Öztürk et al. 2001). The results of the present study are alarming and show that marine traffic in the Istanbul Strait is hav- 
ing a strong behavioural impact on the local bottlenose dolphins. In order to prevent long-term negative effects on the population, marine vessel-dolphin interactions in the strait need to be reduced immediately through the designation of 'Particularly Sensitive Sea Areas' with appropriate conservation strategies with respect to area restrictions, vessel speed and vessel density. Further, regular systematic monitoring of the bottlenose dolphins in the area is needed to monitor potential changes in population size and habitat use over time in response to vessel traffic, to help inform management within the Istanbul Strait and neighbouring waters.

\section{CONCLUSIONS}

The current study has advanced our knowledge and understanding of marine traffic impacts on the bottlenose dolphin population within the Istanbul Strait. Results confirm that the current level of marine vessel traffic has negative effects on the behaviour of the bottlenose dolphins to the extent that it alters their daily behavioural budget. A significant reduction in both feeding and resting behaviour is likely to cause a reduction in energy acquisition and an increase in energy expenditure. This is alarming, since repeated behavioural disruptions could end up negatively affecting both survival and reproduction, which ultimately could lead to population-level effects. The results of the study therefore have to be considered immediately to delineate 'Particularly Sensitive Sea Areas' and to adapt species-specific conservation and management strategies, not only in the Istanbul Strait but also in adjacent waters, in order to reduce the risk of long-term negative consequences on bottlenose dolphins in the strait.

Acknowledgements. We thank all of the research assistants, fishermen and villagers who helped us throughout the data collection process, and Istanbul University for their financial support. This work was partly funded by the EC FP7 PERSEUS Project (Grant. Agr. 287600) and by the Scientific Research Projects Coordination Unit of Istanbul University (Project number FOA-2016-20530). We also thank the Directorate General of Coastal Safety for permission to use the Ahirkapi Lighthouse. Moreover, we give a special thank you to Anna M. Meissner for all of her valuable advice, and to Ilke Ertem, Davide Lelong, Caley McIntosh and Sarah Tubbs for improving the manuscript.

\section{LITERATURE CITED}

Aguilar Soto N, Johnson M, Madsen PT, Tyack PL, Bocconcelli A, Borsani JF (2006) Does intense ship noise disrupt foraging in deep-diving cuvier's beaked whales (Ziphius cavirostris)? Mar Mamm Sci 22:690-699

Ameer A (2008) Maritime traffic effects on biodiversity in the Mediterranean Sea: Review of impacts, priority areas and mitigation measures, Malaga, Spain. IUCN Centre for Mediterranean Cooperation PhD thesis, p 184

Atar HH, Ates C (2009) Turklerde tarih boyunca su ürünleri avclloğ [The history of the fishery in Turkey]. Acta Turcica Çevrimiçi Tematik Türkoloji Dergisi. Türk Kültüründe 1:269-281

Bain DE, Smith JC, Williams R, Lusseau D (2006) Effects of vessels on behaviour of southern resident killer whales (Orcinus spp.) 2003-2005. NMFS Contract report no. AB133F05SE3965. National Marine Fisheries Service, National Marine Mammal Laboratory, Seattle, WA

Barr K, Slooten E (1999) Effects of tourism on dusky dolphins at Kaikoura. Conservation Advisory Science Notes: 229. Department of Conservation, Wellington

Bas AA, Öztürk AA, Öztürk B (2015) Selection of critical habitats for bottlenose dolphins (Tursiops truncatus) based on behavioral data, in relation to marine traffic in the Istanbul Strait, Turkey. Mar Mamm Sci 31:979-997

Bas AA, Christiansen F, Öztürk AA, Öztürk B, McIntosh C (2017) The effects of marine traffic on the behaviour of Black Sea harbour porpoises (Phocoena phocoena relicta) within the Istanbul Strait, Turkey. PLOS ONE 12(3): e0172970

Bejder L, Samuels A (2003) Evaluating impacts of naturebased tourism on cetaceans. In: Gales N, Hindell M, Kirkwood R (eds) Marine Mammals: Fisheries, Tourism and Management Issues. CSIRO, Collingwood, p 229-256

Bejder L, Dawson SM, Harraway JA (1999) Responses by Hector's dolphins to boats and swimmers in Porpoise Bay, New Zealand. Mar Mamm Sci 15:738-750

* Bejder L, Samuels A, Whitehead H, Gales N (2006a) Interpreting short-term behavioural responses to disturbance within a longitudinal perspective. Anim Behav 72: 1149-1158

Bejder L, Samuels A, Whitehead H, Gales N and others (2006b) Decline in relative abundance of bottlenose dolphins exposed to long term disturbance. Conserv Biol 20: 1791-1798

Birkun A Jr (2002) Interactions between cetaceans and fisheries in the Black Sea. In: Notarbartolo di Sciara G (ed) Cetaceans of the Mediterranean and Black Seas: state of knowledge and conservation strategies. Report to the ACCOBAMS Secretariat, Monaco, Section 10, p 11

Birkun A (2012) Tursiops truncatus ssp. ponticus. The IUCN Red List of Threatened Species 2012:e.T133714A1777 1698. http://dx.doi.org/10.2305/IUCN.UK.2012.RLTS.T1 33714A17771698.en (accessed 04 February 2017).

Buckstaff KC (2004) Effects of watercraft noise on the acoustic behavior of bottlenose dolphins, Tursiops truncatus, in Sarasota Bay, Florida. Mar Mamm Sci 20:709-725

Campana I, Crosti R, Angeletti D, Carosso L and others (2015) Cetacean response to summer maritime traffic in the Western Mediterranean Sea. Mar Environ Res 109:1-8

Christiansen F, Lusseau D (2014) Understanding the ecological effects of whale watching on cetaceans. In Higham J, Bejder L, Williams R, editors. Whale-watching, sustainable tourism and ecological management. Cambridge University Press, Cambridge. p 177-192

Christiansen F, Lusseau D (2015) Linking behavior to vital rates to measure the effects of non-lethal disturbance on wildlife. Conserv Lett 8:424-431 
Christiansen F, Lusseau D, Stensland E, Berggren P (2010) Effects of tourists boats on the behaviour of Indo-Pacific bottlenose dolphins off the south coast of Zanzibar. Endang Species Res 11:91-99

Christiansen F, Rasmussen MH, Lusseau D (2013) Inferring activity budgets in wild animals to estimate the consequences of disturbances. Behav Ecol 24:1415-1425

Constantine R, Baker CS (1997) Monitoring the commercial swim-with-dolphin operations in the Bay of Islands. Science for conservation report no. 56. Department of Conservation, Wellington

Constantine R, Brunton DH, Dennis T (2004) Dolphinwatching tour boats change bottlenose dolphin (Tursiops truncatus) behaviour. Biol Conserv 117:299-307

* Dans SL, Crespo EA, Pedraza SN, Degrati M, Garaffo GV (2008) Dusky dolphin and tourist interaction: effect on diurnal feeding behaviour. Mar Ecol Prog Ser 369:287-296

* Deniz C, Durmuşoğlu Y (2008) Estimating shipping emissions in the region of the Sea of Marmara, Turkey. Sci Total Environ 390:255-261

Directorate General of Coastal Safety (2014) Annual Report. T.C Ulaştırma, Denizcilik ve Haberleşme Bakanlıgı, www.kiyiemniyeti.gov.tr (accessed 20 Jan 2017)

Fleiss JL (1981) The measurement of interrater agreement. In: Statistical methods for rates and proportions, 2nd edn. John Wiley, New York, NY, p 212-236

*Foote AD, Osborne RW, Hoelzel AR (2004) Whale-call response to masking boat noise. Nature 428:910

Gordon J, Leaper R, Hartley FG, Chappell O (1992) Effects of whale-watching vessels on the surface and underwater acoustic behaviour of sperm whales off Kaikoura, New Zealand. Science and Research Series no. 52. Department of Conservation, Wellington

Hastie GD, Wilson B, Tufft LH, Thompson PM (2003) Bottlenose dolphins increase breathing synchrony in response to boat traffic. Mar Mamm Sci 19:74-84

Holt MM, Noren DP, Emmons CK (2012) Does vessel noise affect the use of sound by foraging Orcinus orca (killer whales)? In: Popper AN, Hawkins A (eds) The effects of noise on aquatic life. Advances in experimental biology and medicine, Vol 730. Springer, New York, NY, p 327-330

Kara EG (2016) Risk assessment in the Istanbul Strait using Black Sea MOU port state control inspections. Sustainability (Switzerland) 8(4)

Kight CR, Swaddle JP (2011) How and why environmental noise impacts animals: an integrative, mechanistic review. Ecol Lett 14:1052-1061

Köse E, Başar E, Demirci E, Güneroğlu A, Erkebay Ş (2003) Simulation of marine traffic in Istanbul Strait. Simul Model Pract Theory 11:597-608

Lemon M, Lynch TP, Cato DH, Harcourt RG (2006) Response of travelling bottlenose dolphins (Tursiops aduncus) to experimental approaches by a powerboat in Jervis Bay, New South Wales, Australia. Biol Conserv 127:363-372

Lusseau D (2003) Effects of tour boats on the behaviour of bottlenose dolphins: using Markov chains to model anthropogenic impacts. Conserv Biol 17:1785-1793

Lusseau D (2004) The hidden cost of tourism: detecting longterm effects of tourism using behavioural information. Ecol Soc 9:2

Kusseau D (2005) Residency pattern of bottlenose dolphins Tursiops spp. in Milford Sound, New Zealand, is related to boat traffic. Mar Ecol Prog Ser 295:265-272

Lusseau D (2006) The short-term behavioural reactions of bottlenose dolphins to interactions with boats in Doubtful
Sound, New Zealand. Mar Mamm Sci 22:802-818

*Lusseau D, Slooten L, Currey RJ (2006) Unsustainable dolphin-watching tourism in Fiordland, New Zealand. Tour Mar Environ 3:173-178

Lusseau D, New L, Donovan C, Cheney B, Thompson PM, Hastie G, Harwood J (2011) The development of a framework to understand and predict the population consequences of disturbances for the Moray Firth bottlenose dolphin population. Scottish Natural Heritage Comissional Report No. 468, Inverness

Mavrakis D, Kontinakis N (2008) A queueing model of maritime traffic in Bosporus Straits. Simul Model Pract Theory 16:315-328

* Meissner AM, Christiansen F, Martinez EM, Pawley MDM, Orams MB, Stockin KA (2015) Behavioural effects of tourism on oceanic common dolphins, Delphinus sp., in New Zealand: the effects of Markov analysis variations and current tour operator compliance with regulations. PLOS ONE 10:e0116962

* Neumann DR (2001) Seasonal movements of short-beaked common dolphins (Delphinus delphis) in the north-western Bay of Plenty, New Zealand: Influence of sea surface temperature and El Niño/La Niña. NZ J Mar Freshw Res 35:371-374

* Neumann DR, Orams MB (2006) Impacts of ecotourism on short-beaked common dolphins (Delphinus delphis) in Mercury Bay, New Zealand. Aquat Mamm 32:1-9

*New LF, Clark JS, Costa DP, Fleishman E and others (2014) Using short-term measures of behaviour to estimate long-term fitness of southern elephant seals. Mar Ecol Prog Ser 496:99-108

Notarbartolo di Sciara G (2002) Cetaceans of the Mediterranean and Black Seas: state of knowledge and conservation strategies. ACCOBAMS Interim Secretariat report, ACCOBAMS, Monaco

Nowacek SM, Wells RS, Solow AR (2001) Short term effects of boat traffic on bottlenose dolphins, Tursiops truncatus, in Sarasota bay, Florida. Mar Mamm Sci 17:673-688

Özsoy E, Çağatay MN, Balkıs N, Balkıs N, Öztürk B (eds) (2016) The Sea of Marmara; Marine Biodiversity, Fisheries, Conservation and Governance. Turkish Marine Research Foundation (TUDAV), Publication No: 42, Istanbul

Öztürk B, Öztürk AA (1996) On the biology of the Turkish straits system. Bull Inst Oceanogr 17:205-221

Öztürk B, Öztürk AA, Algan N (2001) Ship originated pollution in the Turkish Straits System. In: Öztürk B, Algan N (eds) Proc Int Symp on the Problems of Regional Seas, 12-13 May 2001. Turkish Marine Research Foundation Publications, Istanbul, p 86-94

Perez-Jorge S, Louzao M, Oro D, Pereira T and others (2017) Estimating the cumulative effects of the nature-based tourism in a coastal dolphin population from southern Kenya. Deep Sea Res II 140:278-289

Pirotta E, Merchant ND, Thompson PM, Barton TR, Lusseau D (2015) Quantifying the effect of boat disturbance on bottlenose dolphin foraging activity. Biol Conserv 181: 82-89

$\mathrm{R}$ Core Team R (2014) A language and environment for statistical computing. R Foundation for Statistical Computing, Vienna. www.r-project.org

Richardson WJ, Greene CR, Malme CI, Thomson DH (1995a) Marine mammals and noise. Academic Press, San Diego, CA

Richardson WJ, Finley KJ, Miller GW, Davis RA, Koski WR (1995b) Feeding, social and migration behaviour of bow- 
head whales, Balaena mysticetus, in Baffin Bay vs. the Beaufort Sea - regions with different amounts of human activity. Mar Mamm Sci 11:1-45

Saulitis E, Matkin C, Barrett Lennard L, Heise K, Ellis G (2000) Foraging strategies of sympatric killer whale (Orcinus orca) populations in Prince William Sound, Alaska. Mar Mamm Sci 16:94-109

Stockin KA, Lusseau D, Binedell V, Wiseman N, Orams MB (2008) Tourism affects the behavioural budget of the common dolphin Delphinus sp. in the Hauraki Gulf, New Zealand. Mar Ecol Prog Ser 355:287-295

Tixier P, Gasco N, Duhamel G, Guinet C (2015) Habituation to an acoustic harassment device (AHD) by killer whales

Editorial responsibility: Nils Bunnefeld, Stirling, UK depredating demersal longlines. ICES J Mar Sci 72: 1673-1681

*Van Parijs SM, Corkeron PJ (2001) Boat traffic affects the acoustic behaviour of Pacific humpback dolphins, Sousa chinensis. J Mar Biol Assoc UK 81:533-538

* Visser F, Hartman KL, Rood EJJ, Hendriks AJE and others (2011) Risso's dolphins alter daily resting pattern in response to whale watching at the Azores. Mar Mamm Sci 27:366-381

Williams AP, R Seager JT, Abatzoglou BI, Smerdon JE, Cook ER (2015) Contribution of anthropogenic warming to California drought during 2012-2014. Geophys Res Lett 42(16):6819-6828

Submitted: September 26, 2016; Accepted: May 1, 2017

Proofs received from author(s): July 7, 2017 